\title{
The Well-Being Gap during the Great Recession: The Role of Growth and Institutions
}

\author{
Marco Ciziceno ${ }^{1} \&$ Pietro Pizzuto ${ }^{1, *}$ \\ ${ }^{1}$ Department of Economics, Business and Statistics (SEAS), University of Palermo, Viale delle \\ Scienze, Building 13, 90128 - Palermo, Italy \\ *Corresponding author: Department of Economics, Business and Statistics (SEAS), University \\ of Palermo, Viale delle Scienze, Building 13, 90128 - Palermo, Italy \\ Marco Ciziceno and Pietro Pizzuto have contributed equally to this work.
}

Received: March 22, 2020 Accepted: April 5, 2020 Published: June 1, 2020

doi: 10.5296/rae.v12i2.16728 URL: https://doi.org/10.5296/rae.v12i2.16728

\begin{abstract}
The purpose of this paper is to examine the well-being dynamics across European countries during the Great Recession and to investigate the potential role of the quality of formal institutions in mitigating the negative effect of the economic downturn. This study uses the club convergence methodology by Phillips and Sul $(2007 ; 2009)$ to group EU-28 countries that present similar features in terms of well-being during the period 2005-2017. The study also applies probit models to investigate the potential role of several social and institutional characteristics that are supposed to affect subjective well-being levels. The results show the existence of a "well-being gap" among European countries. The economic downturn started in 2008 has impacted the perceived well-being more in low-income and low-growth countries (less developed transition and Southern countries), than in high-income and more developed transition countries. The study also shows that countries that present well-functioning institutional systems and, more in general, good institutional performances show higher life satisfaction levels and tend to be more resilient to the negative effects generated by the economic shock.
\end{abstract}

Keywords: economic crisis, subjective well-being, Europe, happiness gap, convergence clubs 


\section{Introduction}

The political reforms introduced over the last decades have gradually attenuated disparities between transition and advanced countries with advisable improvements in the macroeconomic conditions both in less developed areas of Europe (Gruen and Klasen, 2012) and in the postcommunist countries (Iwanicz-Drozdowska et al., 2016; Blokker, 2005).

However, the global financial crisis of 2008 has slowed down the difficult process of convergence among European countries (Bolea et al., 2018; Kelley and Evans, 2017; Mazzola and Pizzuto, 2020). Emerging literature on the relationship between macroeconomic development and life evaluation (Guriev and Melnikov, 2018; Arampatzi et al., 2019), indicates that the economic crisis has also extended its effects on individuals' perception about their life (happiness or life satisfaction) (see also Delle Fave, 2014; Helliwell et al., 2014a). Nonetheless, while an increasing amount of studies has addressed the impact of the financial crisis in terms of income, productivity and employment convergence, less attention has been paid to the analysis of its effect on subjective well-being convergence. Previous studies (see for example, Welsch and Bonn (2008) and Djankov et al. (2016)) have suggested a possible association between economic and well-being convergence in the European context, but the reason why some countries appear to be more resilient to crises than others - in terms of subjective wellbeing - is still unsolved.

In this paper we try to fill this gap by investigating the asymmetric effects of the financial crisis of 2008 upon people's well-being, by comparing transition countries (i.e., Eastern and Central European members) vis-à-vis developed countries (i.e., original European members). We analyze life satisfaction data from 2005 to 2017 in order to understand whether - or not - the subjective well-being in transition countries converges to the levels of other EU members, but also, to what extent this process may depend on institutional, social or economic conditions.

By using the approach proposed by Phillips and Sul $(2007 ; 2009)$ we cluster EU countries that present similar dynamics in life satisfaction during the period analyzed. Our results suggest the presence of a "well-being gap" among European countries and indicate that the levels of subjective well-being converge to different steady-states, by forming at least three groups of countries. We also find that in some transition economies (less developed) and in peripheral countries (Southern European countries) life satisfaction is extremely sensitive to the economic business cycle and, conversely, in other parts of Europe life satisfaction flows independently from GDP growth. In addition, by using an ordered-probit model we investigate several institutional and contextual (i.e., social and demographic) characteristics of each country that are supposed to affect the subjective well-being levels.

This paper is related to three streams of the literature. The first is on the link between income, economic growth and growth in life satisfaction (Easterlin, 1974; Diener and Biswas-Diener 2002; Deaton 2008). The second is on the disparities in well-being (i.e., happiness gap) among transition and advanced economies (Guriev and Zhuravskaya, 2009) and, finally, the third is on its possible determinants (Gruen and Klasen, 2012; Djankov et al., 2016; Nikolova, 2016).

In particular, we contribute to the existing literature in several ways. First, the methodology 
adopted in this paper (Phillips and Sul 2007; 2009) enables the endogenous determination of groups of countries with similar patterns in life satisfaction, unlike previous studies in which countries are grouped a priori (Djankov et al., 2016; Nikolova, 2016). Second, we highlight that the progress achieved by European transition countries in the economic sphere has partly failed to translate into improvements in terms of well-being and we demonstrate how disparities in well-being among transition and advanced economies have increased after the recent crisis. Third, in line with previous research on economic performances, good governance and life satisfaction (see for example Frey and Stutzer, 2000, 2002; Bjørnskov et al., 2007, 2010) our findings indicate that well-functioning institutions(note 1) matter also in time of crisis, since they appear to offset the negative effects on life satisfaction levels produced by the economic shock.

Implications of this study may be used to inform policymakers about the effects of economic crises on people's life satisfaction both in advanced and transition countries. Particularly, the fact that people's life satisfaction in countries with relatively poor quality of institutions appear to be lower and more sensitive to the economic cycle, suggests to strengthen those public institutions in order to ensure a higher level of well-being and make it less sensitive to economic shocks.

The remainder of the paper is organized as follows. The next section provides a review of the existing literature. Section 3 describes the data and presents the methodology. Sections 4 and 5 discuss the results. Finally, section 6 concludes by discussing some interpretations and policy implications.

\section{Life Satisfaction and Economic Performances}

In recent years, growing attention has been paid to the subjective well-being (SWB) surveys as complementary metrics to assess the success - or the failure - of public policies. By definition, subjective well-being (SWB) is the combination of people's life satisfaction and individuals' emotions (i.e., pleasant affect and unpleasant affect) in response to daily events (Andrews and Crandall, 1976; Diener et al., 1985; MacLeod, 2015). Life satisfaction is a separable construct of SWB (Lucas et al. 1996) that could be analyzed independently because it is less sensitive to cultural differences and it tends to remain more stable over time (Fujita and Diener 2005). As a result, scientific research often relies on life satisfaction as a brief measure of subjective wellbeing and the inclusion of life satisfaction in several international surveys is now a wellestablished practice.(note 2)

A large literature has looked at the relationship between per-capita income, economic growth and life satisfaction. The mainstream literature indicates that people's subjective well-being rises in line with GDP growth and personal income, although evidence suggests that this relation is not stable and tends to remain stationary over a satiation point (i.e., the Easterlin Paradox - Easterlin, 1974). For example, Diener and Biswas-Diener (2002) in a systematic review on the income-subjective well-being association, pointed out that people living in richer countries tend to judge themselves as more satisfied (i.e., they reported higher scores of 
subjective well-being) compared to people living in poorer countries. Headey and Wooden (2004) using data drawn from the Household, Income and Labor Dynamics in Australia (HILDA) Survey, analyzed the wealth, income and subjective well-being issues for a large sample of people. They found that personal income has a statistically significant - but relatively small - effect on people's well-being, whereas wealth seems to exert a greater effect.

By contrast, other studies have shown that the association between income and subjective wellbeing is affected by supplementary factors. For example, Di Tella and McCulloch (2008) in a comparative study between Europe and the U.S. found that income rises happiness, but this relationship is impaired by other non-economic factors that depress well-being, such as unemployment rates, levels of crime and individuals' specific characteristics. Frijters et al. (2004) studied the life satisfaction convergence during the post-reunification years in Germany. The authors found that life satisfaction in East Germany immediately reached the level of West Germany after the reunification. However, the process of convergence in life satisfaction was only in part explained by economic factors (i.e., a large increase in real household incomes) and it was also the result of improvements realized in the public sector and the gradual release of personal freedom. Welsch and Bonn (2008) found convergence in life satisfaction across EU-12 members for the period 1991-2003 mainly explained by convergence in macroeconomic conditions (i.e., inflation, unemployment rates and income levels). Okulicz-Kozaryn (2012) applied a spatial modelling in the context of European regions and he found that life satisfaction is spatially correlated, with clusters of happy and unhappy provinces that influence each other.

Other recent studies, instead, have focused on the investigation of the "happiness gap" in transition countries. Particularly, they have analyzed the fact that countries that have undergone large-scale economic transformations (i.e., the transition from plan to market in postcommunist countries) with income gains, have partly failed to translate them into improvements in well-being. For example, Guriev and Zhuravskaya (2009) examining the differences between transition and non-transition countries (including advanced and developing countries) claimed that the transition from communism to a more market-oriented economy did make people unhappy. They found a strong association of happiness with income in transition countries, with a relevant role in explaining the gap played by the depreciation of education acquired under socialism, public goods deterioration, and income inequality. Gruen and Klasen (2012) examined the well-being trends in the former Soviet Bloc countries from 1988 to 2008 and they found that along some dimensions (i.e., civic liberties) the transition process has been a success, but in terms of well-being the majority of countries showed the same levels of the pre-transition period. Djankov et al. (2016), investigated the persistence of disparities in well-being between transition and developed countries indicating the lack of good governance as cause of this gap. Nikolova (2016) focused on the rule of law as an additional institutional factor playing a role in reducing the happiness gap between transition and advanced Western nations. Conversely, Northon et al. (2018) referred to unemployment dynamics to explain the transition happiness gap in Ukraine.

In this context, despite the numerous investigations on per-capita GDP growth and growth in well-being, studies that explore this relationship during the Great Recession period are limited. The little evidence existing in literature documents that the macroeconomic changes due the 
recent economic crisis have generated an aggregate and individual-level consequences either in terms of negative health outcome (Burgard and Kalousova, 2015), mental disorders (Modrek et al., 2015) and reduced levels of well-being (Graham et al., 2010; Deaton, 2012). Other studies, instead, have looked at the moderating role of social capital (Helliwell et al., 2014a) and quality of governance (Arampatzi et al., 2019). However, these investigations are prevalently focused on the U.S. and until now how the Great Recession impacted subjective well-being in Europe is a little explored question.

\subsection{Data}

We use Eurobarometer survey data for the period 2005-2017(note 3). The data, available on a semi-annual basis, covers the full panel of European Union Members (Austria, Belgium, Bulgaria, Croatia, Cyprus, Czech Republic, Denmark, Estonia, Finland, France, Germany, Greece, Hungary, Ireland, Italy, Latvia, Lithuania, Luxembourg, Malta, Netherlands, Poland, Portugal, Romania, Slovakia, Slovenia, Spain, Sweden) plus the United Kingdom. The Eurobarometer survey is the instrument through which the European Commission collects information about the citizens of Member States on a broad variety of social, political and economic issues. Among these, we have exploited questions related to the households' living conditions and citizens' opinions about their life. Particularly, in order to assess people's life satisfaction, respondents are requested to answer to the following question: "On the whole, how satisfied are you with your life?". A four-point scale ranging from 1 "not at all satisfied" to 4 "very satisfied" indicate the overall level of individuals' life satisfaction. As reference category for our study, we use the percentage of the population answering "very satisfied" (i.e., the top category), since the extremes of life satisfaction scale are usually considered more stable over time and less sensitive to cultural differences (Bjørnskov et al., 2007; 2010).

\subsection{Methodology}

To investigate the presence of convergence in life satisfaction across European countries, we follow the methodology developed by Phillips and Sul (2007, 2009). Unlike other approaches in which countries are grouped a priori, this methodology enables the endogenous determination of convergence clubs and under the hypothesis of convergence, different transitional paths are possible. Particularly, they propose a modification to the conventional panel data decomposition of the variable of interest (in our case a proxy of life satisfaction, $X_{i t}$ ). In fact, usually panel data are decomposed in the following way:

$$
X_{i t}=\partial_{i} \mu_{t}+\varepsilon_{i t}
$$

where $\partial_{i}$ the systematic factor (the unit characteristic component), $\mu_{t}$ is the common factor and $\varepsilon_{i t}$ is the error term. Phillips and Sul $(2007,2009)$ modify equation (1) in order to account for temporal transitional heterogeneity:

$$
X_{i t}=\partial_{i t} \mu_{t}
$$

In this case, the systematic idiosyncratic element $\partial_{i t}$ is allowed to evolve over time and include a random component that absorbs $\varepsilon_{i t}$, while, the common growth component $\mu_{t}$ may follow either a trend-stationary process or a non-stationary stochastic trend with drift. A 
particular assumption regarding the behavior of $\mu_{t}$ is not necessary. Using the dynamic factor formulation described in equation (2), $\partial_{i t}$ represents the transition path of the economy to the common steady-state growth path determined by $\mu_{t}$.

In order to test whether the life satisfaction of different economies converges, we need to estimate $\partial_{i t}$. The authors propose the construction of the following relative transition component:

$$
h_{i t}=\frac{X_{i t}}{N^{-1} \sum_{i=1}^{N} X_{i t}}=\frac{\partial_{i t}}{N^{-1} \sum_{i=1}^{N} \partial_{i t}}
$$

that can be directly computed from the data.

The coefficient $h_{i t}$ is called "relative transition path", and it is obtained by dividing the life satisfaction of country $i$ by the average life satisfaction of the economies under objective. In this way we are able to remove the common steady-state trend $\mu_{t}$, tracing an individual trajectory for each economy $i$ in relation to the panel average. In other words, the relative transition path describes the relative individual behavior as well as the relative departures of economy $i$ from the common path $\mu_{t}$.

According to this framework, convergence is detected when there is a common limit in the transition path of each economy. Specifically, the coefficient $h_{i t}$ should converge towards unity $\left(h_{i t} \rightarrow 1\right.$, for all $i$, as $\left.t \rightarrow \infty\right)$, and the cross-sectional variation $H_{i t}$ (computed as the quadratic distance measure for the panel from the common limit) should converge to zero:

$$
H_{t}=N^{-1} \sum_{i=1}^{N}\left(h_{i t}-1\right)^{2} \rightarrow 0 \quad \text { as } t \rightarrow \infty
$$

More formally, to test for the presence of convergence among different economies, the following equation has to be estimated by ordinary least squares methodology:

$$
\begin{aligned}
& \log \frac{H_{1}}{H_{t}}-2 \log (\log t)=a+\beta \log t+u_{t}, \\
& \text { for } t=\left[r T_{0}\right],[r T]+1, \ldots, T
\end{aligned}
$$

where $H_{t}=N^{-1} \sum_{i=1}^{N}\left(h_{i t}-1\right)^{2}$ and $H_{1} / H_{t}$ is the cross-sectional variance ratio; $\beta$ represents the speed of convergence parameter of $\partial_{i t} ;-2 \log (\log t)$ is a penalization function that improves the performance of the test mainly under the alternative; $r$ assumes a positive value in order to discard the first block of observation from the estimation, and $[r T]$ is the integer part of $r T$. (note 4) The null hypothesis of convergence is tested through a one-sided $t$-test robust to heteroskedasticity and autocorrelation (HAC) and it is rejected at the $5 \%$ level if $t_{\widehat{\beta}}<-1.65$.

This procedure, generally called "log $t$-test", has power against cases of club convergence. Hence, if the $\log t$-test is rejected for the whole sample, the authors suggest to repeat the test procedures according to a clustering mechanism consisting of four steps: 1) cross-section last observation ordering; 2) core group formation of size $k^{*}$ obtained running the $\log t$ regression satisfying the condition $k^{*}=\arg \max _{k}\left\{t_{k}\right\}$ subject to $\min \left\{t_{k}\right\}>-1.65 ; 3$ ) club formation 
achieved adding (one by one) each unit $i$ not belonging to the core group that satisfies the condition $\left.\left\{t_{(k+i)}\right\}>c * ; 4\right)$ recursion and stopping rule: if there are units for which the previous condition fails, gather all these units in one group and run the log- $t$ test to see if the condition $\left\{t_{k}\right\}>-1.65$ holds. If the condition is satisfied, conclude that there are two convergence clubs. Otherwise, step 1 to 3 should be repeated, until no $k$ in step 2 satisfies the condition $\left\{t_{k}\right\}>-1.65$ and the remaining regions diverge.

Due to the fact that, in presence of transition across clubs (i.e. part of one club tend to move towards another club) or highly conservative values of some parameters (i.e. $c^{*}$ ), there could be an over determination of the groups, the authors proposed a "club merging algorithm" that is adopted in this paper (see Phillips and Sul 2009). As a robustness check, we also apply a recent club merging algorithm developed by von Lyncker and Thoennessen (2017).(note 5)

\section{Results}

\subsection{Preliminary Results (Descriptive Statistics)}

As a first step to analyze the evolution of life satisfaction over the crisis period, Table A1 in the appendix presents some descriptive statistics on the percentage of people very satisfied with their lives. As already indicated by previous studies (i.e. Bjørnskov et al., 2007; 2010), the countries in which people are more satisfied with their life are the Northern European countries such as Denmark, The Netherlands and Sweden. Specifically, the average value in Denmark, the most satisfied country, is $68.5 \%$ with a maximum value of $72.7 \%$. The countries in the middle of the distribution present scores ranging from $16 \%$ to $30 \%$. (i.e. France, Austria, Belgium, Germany). On the contrary, less satisfied people live in Southern and Eastern European countries. In the majority of them, very satisfied people are below $10 \%$ with Portugal that had the worst performance, reporting an average value of $3.57 \%$.

In addition, Table A1 shows the overtime coefficient of variation of life satisfaction for each country. From a quick look, we can see how heterogeneity in behaviors seems to be in place. In fact, the value of the coefficient of variation is very small in some cases (i.e., Sweden, Netherlands, Belgium) signaling greater stability in life satisfaction over the time, whilst it is larger in other countries (i.e., Greece, Bulgaria, Portugal) indicating higher variability.

When looking at the relationship between life satisfaction and per-capita GDP levels, the positive association already observed in literature is confirmed. Figure 1 shows that life satisfaction is higher in countries with higher levels of GDP per head. 


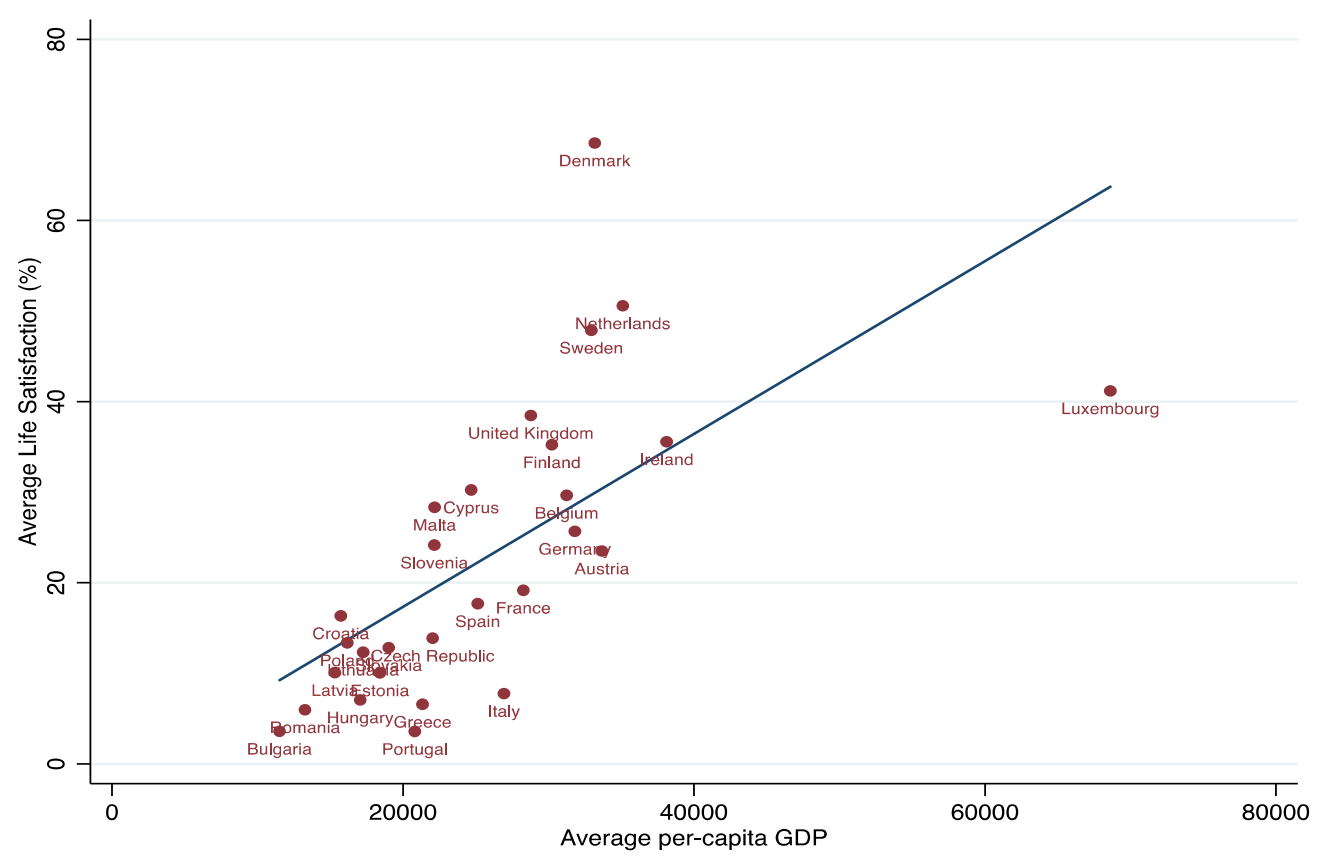

Figure 1. Life Satisfaction and Per-Capita GDP in Europe

Note: Per-capita GDP is measured in purchasing power standard (PPS) euro at market prices.

When we compare the overtime dispersion among countries of these two indicators, we observe different patterns (Figure 2). On the one hand, life satisfaction disparities, measured by the coefficient of variation, increased almost constantly until 2013 when they started falling to a point below the starting level. On the contrary, after a sharp decrease before the outbreak of the crisis, the dispersion in per-capita GDP levels fluctuated little, registering a marked increase in the period 2013-2015, followed by signals of decrease.
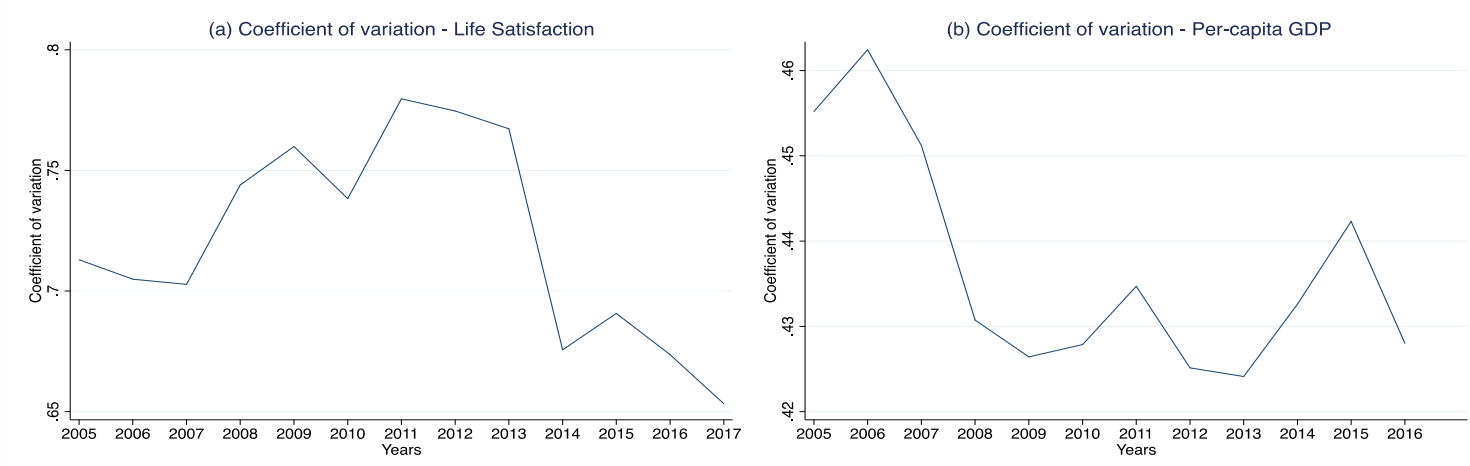

Figure 2. Dispersion in Life Satisfaction and Per-Capita GDP in Europe 


\section{Macrothink}

The stylized facts presented in this paragraph indicate that although the positive association between life satisfaction and per-capita GDP levels seem to be confirmed, unclear remains the relationship between life satisfaction and economic growth. Beyond the synthetic measures presented, a more complex picture seems to exist. Specifically, the heterogeneity in the data suggests the existence of diverse well-being and GDP growth patterns in Europe and this is the reason why we use the club convergence methodology described in the previous paragraph to investigate the presence of a "well-being gap" in the European context and the effects produced by the Great Recession.

\subsection{Convergence Clubs in Life Satisfaction and the Effects of the Great Recession}

The heterogeneity in life satisfaction patterns across the European countries is confirmed by the application of the log- $t$ test to the overall sample of 28 Countries that yields to the rejection of the null hypothesis of absolute (unconditional) convergence at the $1 \%$ significance level ( $t$ value $=-24.15)$. (note 6$)$ This means that the countries do not converge to the same steady-state, and therefore, we follow the clustering procedure proposed by Phillips and Sul to investigate the presence of convergence clubs.

The results of this exercise are shown in Table 1 and suggest the presence of four clubs that converge towards four different steady-states. The $t$-stats for each club are greater than -1.65 and, therefore, indicate the presence of significant (though weak) convergence within each club.(note 7) As a robustness check, the application of the two club merging algorithms earlier discussed reduces the number of detected clubs to three by merging the latest two clubs, with $11,10$ and 6 countries, respectively (Table 2$)$.(note 8 )

Table 1. Convergence Clubs in Life Satisfaction (Baseline)

\begin{tabular}{|c|c|c|c|c|c|}
\hline Club & n. Countries & Members & beta & se & t-stat \\
\hline 1 & 11 & $\begin{array}{l}\text { Sweden, United Kingdom, Ireland, Finland, } \\
\text { Luxembourg, Austria, Germany, Netherlands, Slovenia, } \\
\text { Cyprus, Malta }\end{array}$ & -0.068 & 0.046 & -1.480 \\
\hline 2 & 10 & $\begin{array}{l}\text { Belgium, France, Spain, Czech Republic, Poland, } \\
\text { Lithuania, Latvia, Estonia, Hungary, Romania }\end{array}$ & -0.057 & 0.057 & -1.007 \\
\hline 3 & 4 & Croatia, Slovakia, Bulgaria, Portugal & 0.063 & 0.131 & 0.479 \\
\hline 4 & 2 & Italy, Greece & 0.199 & 0.275 & 0.725 \\
\hline
\end{tabular}

Note: Denmark is diverging country. 


\section{Macrothink}

Table 2. Convergence Clubs in Life Satisfaction (Club Merging Methodologies)

\begin{tabular}{|c|c|c|c|c|c|}
\hline Club & n. Countries & Members & beta & se & t-stat \\
\hline 1 & 11 & $\begin{array}{l}\text { Sweden, United Kingdom, Ireland, Finland, } \\
\text { Luxembourg, Austria, Germany, Netherlands, } \\
\text { Slovenia, Cyprus, Malta }\end{array}$ & -0.068 & 0.046 & -1.480 \\
\hline 2 & 10 & $\begin{array}{l}\text { Belgium, France, Spain, Czech Republic, Poland, } \\
\text { Lithuania, Latvia, Estonia, Hungary, Romania }\end{array}$ & -0.057 & 0.057 & -1.007 \\
\hline 3 & 6 & Croatia, Slovakia, Bulgaria, Portugal, Italy, Greece & -0.092 & 0.112 & -0.821 \\
\hline
\end{tabular}

Note: Denmark is diverging country

The first club identified is prevalently composed of Northern European countries (with the exception of Slovenia, Cyprus and Malta) and presents the higher average value in life satisfaction (39.2\%). The second club mainly includes most of the Eastern and Central European countries with the exception of some original EU countries characterized by a lower level of well-being with respect to Northern European countries. Whereas the last club, composed of less developed transition economies and Southern European countries, shows the lowest levels in life satisfaction (9.2\%).(note 9) Results of club convergence analysis partly reflect the results obtained by previous studies indicating the Nordic countries as those with higher life satisfaction (see Bjørnskov, 2003), contrary to the Southern European countries generally characterized by lower life satisfaction and lower social capital, and the transition countries lagging behind both in terms of income and well-being (Guriev and Zhuravskaya, 2009; Gruen and Klasen, 2012; Nikolova, 2016). However, an interesting dichotomy among transition countries emerges. Some countries have made progress and are approaching the life satisfaction levels of some original EU members (i.e. France, Spain, Belgium). Conversely, other low-income transition economies are lagging behind by forming a club with low-growth Southern European countries.

As earlier discussed, the economic crisis may have extended its negative effects on individuals' perceptions about their life and these effects may be asymmetric across countries. To address these points, we firstly look at the evolution of the average value of very satisfied people across our panel of countries. As Figure 3 shows, the Great Recession had a harmful effect on the well-being of European citizens. In fact, people's life satisfaction started decreasing in 2007 reaching the lowest level in 2013. During this period, the average level of very satisfied people fell down by 1.6 points moving from $22.5 \%$ to $20.9 \%$. After that, people's life satisfaction increased constantly reaching the average value of $25.8 \%$. 


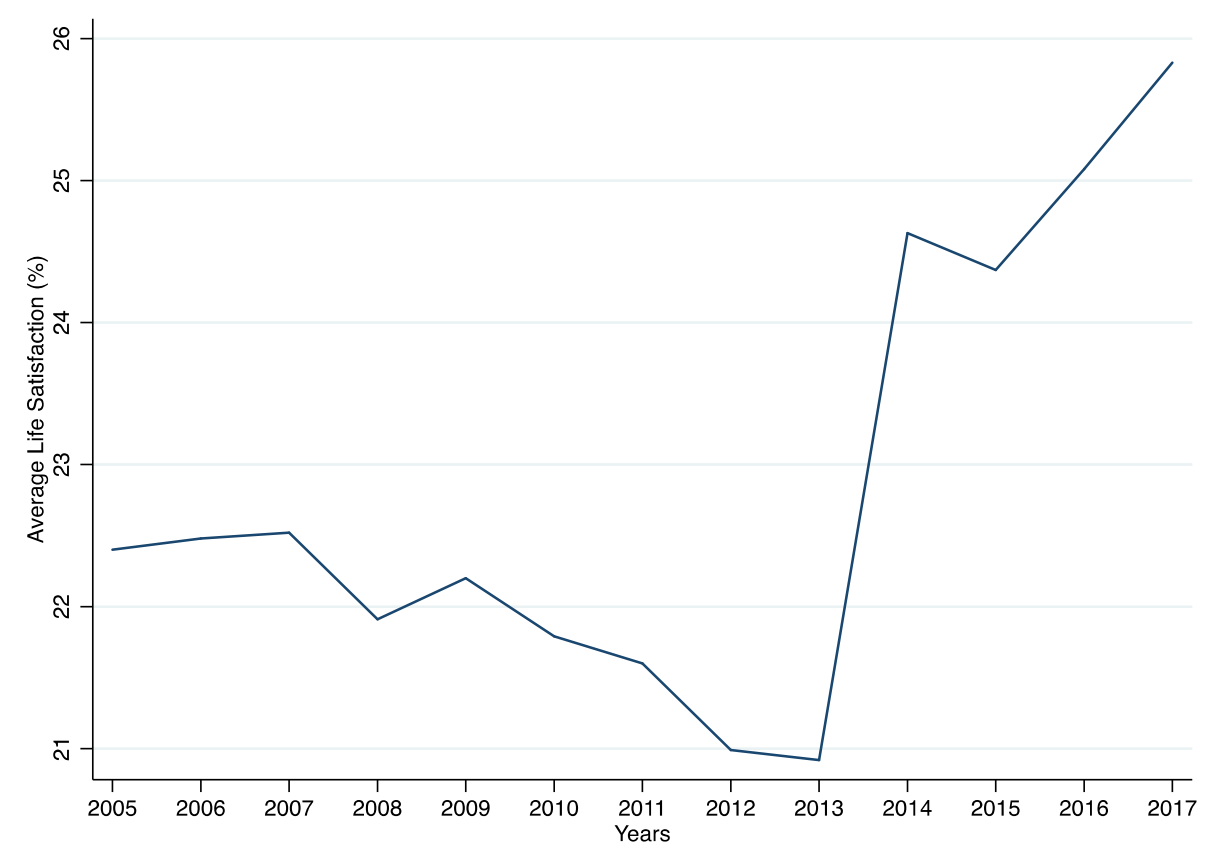

Figure 3. Average Life Satisfaction level in Europe (2005-2017)

However, the Great Recession seems to have had heterogeneous effects across countries. In Table 3 we compare life satisfaction levels of 2008 with those of 2017 and we find a clear divergent impact of the crisis among the groups under consideration. In fact, although in all clubs the average life satisfaction is higher in last year respect to 2008 , the underlying processes happened with very different speeds. In the first and the second clubs, life satisfaction recovered at a faster pace than the third club, thus increasing the distance among countries.

Table 3. Life Satisfaction by Club

\begin{tabular}{ccccc}
\hline Club & Average 2008 & Average 2017 & Var. (\%) & Var. (level) \\
\hline 1 & $33.8 \%$ & $39.2 \%$ & $16.0 \%$ & 5.4 \\
2 & $13.6 \%$ & $17.0 \%$ & $25.0 \%$ & 3.4 \\
3 & $8.2 \%$ & $9.2 \%$ & $12.2 \%$ & 1.0 \\
\hline
\end{tabular}

Note: values in 2008 and 2017 indicate the average percentage of very satisfied of each club

To shed more light on this point we also look at the overtime distance between the average level of life satisfaction of each club. Looking at Figure 4, the distance between the first and the third club rose initially (until 2009), then fluctuated around 25 points without showing a clear pattern up to 2013. Conversely, after 2013 the distance between the clubs started increasing sharply, reaching almost 30 points in 2017 . The distance between the average level 


\section{Macrothink}

of life satisfaction of clubs 1 and 2 showed a very similar pattern, though to a lesser extent. After a fluctuation of around 20 points, it reached the minimum value of 18 points in 2013 , rising quickly to 22.8 points in 2017. Finally, the distance between the second and the third club showed a clear increasing pattern over the period considered. Except for a slight decrease occurred between 2009 and 2010, the distance between the average level of life satisfaction of the two clubs shifted from 5.4 points in 2008 to 7.2 points in 2017.

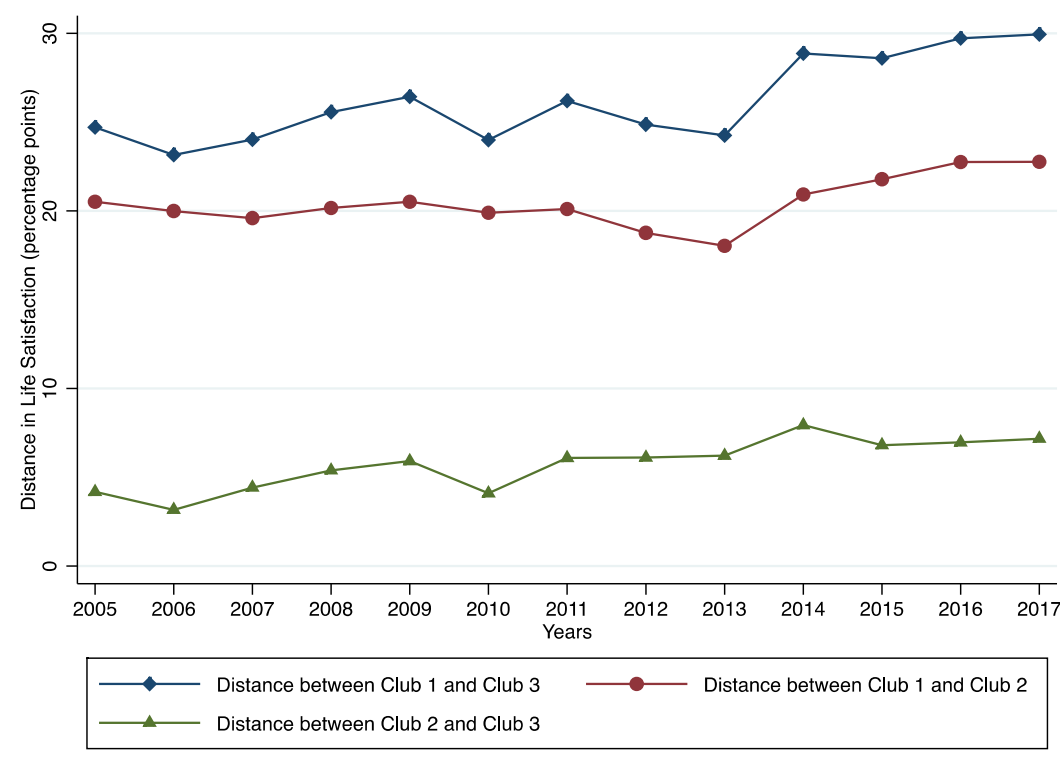

Figure 4. Distance in Life Satisfaction between Clubs

\section{Factors Affecting Life Satisfaction and Group Membership}

One of the reasons of the heterogeneity shown in the previous section may be the different impact of the economic crisis on per-capita income across countries. In fact, as earlier discussed, there should be a positive, though weak, association between income and subjective well-being. As a consequence, we expect that people living in richer countries should be, also, more satisfied with their life, and to more resilient countries should be associated higher levels of life satisfaction.

On the one hand, the first hypothesis is also here confirmed. In fact, looking at Table 4 the positive relationship between life satisfaction and per-capita income levels is proved. The higher is the level of per-capita income, the higher is the level of life satisfaction. 
Table 4. Average Per-Capita GDP by Club (Market Prices, Euros, PPS)

\begin{tabular}{cccc}
\hline Club & Average 2008 & Average 2016 & Var. (\%) \\
\hline 1 & 33427 & 37627 & $12.6 \%$ \\
2 & 19990 & 23630 & $18.2 \%$ \\
3 & 19900 & 20767 & $4.4 \%$ \\
\hline
\end{tabular}

Note: values in 2008 and 2016 indicate the average per-capita GDP levels of each club. Percapita GDP data available only up to 2016

To investigate the second hypothesis, Table 4 shows also the cumulative per-capita GDP growth rates for each club. We note that countries belonging to all clubs recovered to pre-crisis levels showing (on average) an aggregate positive growth in per-capita GDP over the period 20082016, though with different speeds. More specifically, though the average per-capita GDP of clubs 2 and 3 were almost the same just before the crisis, we can see a very different reaction to the crisis. Therefore, comparing the results presented in Tables 3 and 4, it seems that the differences in life satisfaction change during the period of crisis may be fully explained by different patterns of economic growth.

However, when we compare the evolution of the subjective well-being over the period of crisis with the annual per-capita GDP growth, the scenario that occurs is different. In fact, looking at the results presented in Figure 5 we observe growth-dependent countries in which life satisfaction is extremely sensitive to the economic business cycle (club 3). Conversely, we also identify groups of countries in which life satisfaction flows independently from per-capita GDP growth (clubs 1 and 2), confirming that the harmful effects of economic crisis have not impacted homogenously life satisfaction. (note 10) 

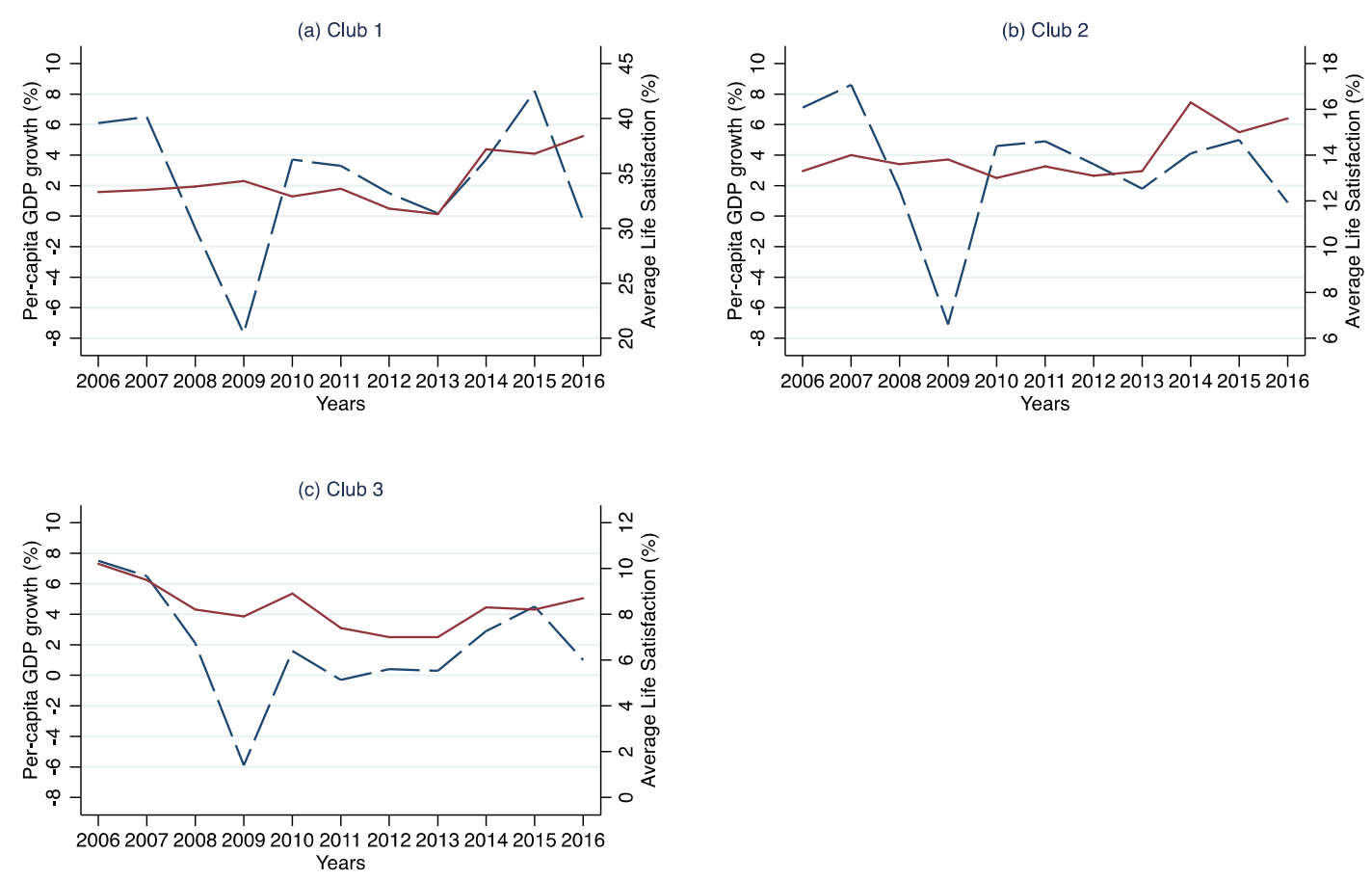

— — — Per-capita GDP growth (left)

Average Life Satisfaction (right)

Figure 5. Life Satisfaction and Per-Capita GDP Growth

The results presented suggest that the composition of each club, and therefore the life satisfaction pathways, seem to be related to per-capita income levels but they do not always depend on GDP growth. However, our results do not exclude the role played by other supplementary factors that may influence the composition of each club. On the basis of previous research on economic performances, good governance and life satisfaction (see for example, Frey and Stutzer, 2000, 2002; Bjørnskov et al., 2007, 2010) we test our hypothesis by considering a set of institutional, socio-economic and demographic dimensions (i.e., proxies of these dimensions) that are supposed to affect life satisfaction (Table 5). 
Table 5. Description of Variables and Sources

\begin{tabular}{|c|c|c|c|}
\hline Features & Indicators & Definitions/Values & Sources \\
\hline \multirow[b]{2}{*}{ Institutional } & $\begin{array}{l}\text { Political Stability and } \\
\text { Absence of Violence- } \\
\text { Terrorism }\end{array}$ & $\begin{array}{l}\text { Perceptions of the likelihood of political } \\
\text { instability and/or politically motivated } \\
\text { violence, including terrorism. }\end{array}$ & World Bank \\
\hline & Control of corruption & $\begin{array}{l}\text { Perceptions of the extent to which public } \\
\text { power is exercised for private gain, including } \\
\text { both petty and grand forms of corruption, as } \\
\text { well as "capture" of the state by elites and } \\
\text { private interests. }\end{array}$ & World Bank \\
\hline \multirow{2}{*}{ Socio-Economic } & Income inequality & Gini Coefficient & Eurostat \\
\hline & Unemployment rates & Unemployed as $\%$ of total population & Eurostat \\
\hline \multirow{2}{*}{ Demographic } & Schooling & $\begin{array}{l}\text { Pupils and Students in all levels of education } \\
\text { (ISCED 0-6) - as \% of total population }\end{array}$ & Eurostat \\
\hline & Age of population & Median Age of population & Eurostat \\
\hline
\end{tabular}

Note: For institutional indicators values range from -2.5 (weak) to 2.5 (strong). For details see Kaufmann et al. (2010).

A descriptive analysis of these variables reveals significant differences between the three clubs (Table 6). The first club of countries performs better in almost all the dimensions analyzed. In fact, countries belonging to the first club show, on average, higher perception of political stability, higher perception of control of corruption, lower income inequality and unemployment, and higher share of students in all levels of education.

Conversely, countries belonging to the third club are those with the worst scores in the indicators analyzed. Table 6 also shows how club 2 is really in a middle position borrowing some features from West countries (i.e. higher schooling and lower age of population) and some others from transition economies (lower political stability and control of corruption and higher income inequality). 
Table 6. Descriptive Statistics

\begin{tabular}{lcccccc}
\hline & $\begin{array}{c}\text { Political } \\
\text { Stability }\end{array}$ & $\begin{array}{c}\text { Control } \\
\text { of corruption }\end{array}$ & $\begin{array}{c}\text { Unemployment } \\
\text { rates }\end{array}$ & $\begin{array}{c}\text { Income } \\
\text { inequality }\end{array}$ & Schooling & $\begin{array}{c}\text { Age } \\
\text { of population }\end{array}$ \\
\hline Club 1 & 1.1 & 1.6 & 4.1 & 27.4 & 23.3 & 38.6 \\
Club 2 & 0.6 & 0.7 & 5.6 & 32.2 & 23.8 & 38.4 \\
Club 3 & 0.6 & 0.4 & 6.4 & 32.2 & 19.9 & 39.6 \\
\hline
\end{tabular}

Note: The numbers indicate the average values of each indicator for each club as indicated in Table 5.

To formally test for the role played by selected variables in the club formation, we estimate several ordered probit models where the variable to be explained is denoted by $y$ and represents the club to which a country belongs. Specifically, the variable of interest is classified as an ordinal variable, where $y=0$ if country- $i$ belongs to Club $3 ; y=1$ if country- $i$ belongs to Club 2; $y=2$ if country- $i$ belongs to Club 1 .(note 11 )

Table 7. Ordered Probit Results

(1)

(2)

0.863

$(0.705)$

Control of corruption

$1.489 * * *$

(0.480)

Unemployment rates

Income inequality

$0.327^{* *}$

(0.132)

$-0.135^{* *}$

(0.0574)
(3)

(4)

(5)

(6)

$1.460^{* *}$

0.575

(0.691)

(0.958)

$.787 * * *$

$1.587 * *$

(0.537)

(0.671)

$-0.355^{* *}$

$-0.373 * *$

(0.141)

$(0.167)$

$\begin{array}{ll}-0.0696 & -0.0871\end{array}$

$(0.0642) \quad(0.0856)$

Schooling

$0.157 * \quad 0.198 * *$

0.141

(0.0829)

(0.0924)

(0.125)

$-0.0531$

(0.117)

$-0.309^{* *}$

-0.352 *

(0.153)

(0.187)

\begin{tabular}{lllllll} 
LR & 19.35 & 13.20 & 4.48 & 18.34 & 23.37 & 30.48 \\
Prob $>$ chi2 & 0.000 & 0.001 & 0.107 & 0.000 & 0.000 & 0.000 \\
Pseudo R $^{2}$ & 0.336 & 0.229 & 0.078 & 0.318 & 0.405 & 0.529 \\
\hline
\end{tabular}

Note: $\quad * \mathrm{p}<0.10 ; * * \mathrm{p}<0.05 ; * * * \mathrm{p}<0.01$ (SE indicated in parentheses)

We estimated the models both according to country-specific institutional, socio-economic, demographic features and including all the variables at the same time (Table 7). We find that 
in the case of the institutional features (model 1), both political stability and control of corruption predict a greater probability of belonging to higher clubs, though only the coefficient associated with the latter variable is statistically significant. Ciziceno and Travaglino (2019) found a potential explanation for this finding in a cross-sectional study between the U.S. and Africa. The authors have demonstrated the existence of a negative indirect effect of perceived corruption on people's life satisfaction via institutional trust. They argued that corruption is not only detrimental per se, but it reduces people's life satisfaction because it implies that public goods are not managed fairly and public institutions represent personal interests instead of general ones. In turn, environments perceived as less stable, less controllable and thus unreliable, expose people to anxiety and stress, reducing their life satisfaction consequently. Moreover, other studies indicate that perceptions people have on how governments actively contrast illegality and corruption have a positive impact on life satisfaction. For example, Bjørnskov et al. (2007), have tested several potential determinants of life satisfaction in more than 70 countries over the time. They found, above all, that good governance and high quality of institutions increase well-being. Helliwell et al. (2014b) investigated the linkage between some features of governance and national well-being in 157 countries over the years 20052012. The authors found that in some cases the quality of institutional performance, whose control of corruption is the core element, matters more for well-being than the per-capita GDP and education levels.

Results from the estimation run on socio-economic dimensions (model 2) confirm our expectations. Countries experiencing higher levels of unemployment rates and income inequality present a greater probability of belonging to lower clubs (and thus display lower levels of life satisfaction). On the one hand, unemployment depresses life satisfaction because it impacts directly and negatively people's cognitive and material spheres and expose individuals to severe psychological stressors (Burgard and Kalousova, 2015). Similarly, Northon et al. (2018) referred to the effect of past and current unemployment to explain the transition happiness gap in Ukraine. On the other hand, our results are in line with OkuliczKozaryn and Mazelis (2017) who found a strong association between income inequality and the "well-being gap" in the U.S. suggesting how today's poor suffer greater relative unhappiness than the poor of past decades.

Looking at the demographic characteristics (model 3), we find that the percentage of schooling increases the likelihood of belonging to the top clubs. In line with our finding, Bjørnskov et al. (2007) suggested that education (i.e., primary and secondary) contributes to people's quality of life since well-educated people are more informed about the state of society and better understand risks and opportunities given them by the external environment. Oishi et al. (1999) drawn to similar conclusions indicating that schooling is conducive to increase life satisfaction, especially in individualist and wealthy societies.

Selecting one variable for each feature, results are confirmed, with the political stability that become statistically significant (models 4 and 5). Finally, considering all the variables (model 6), control of corruption, unemployment rates and age of population remain still significant, indicating the importance of institutional, socio-economic and demographic features in affecting club composition and therefore life satisfaction levels. (note 12) 


\section{Conclusions and Policy Implications}

In this paper, we have attempted to shed further lights on the relationship between economic growth, per-capita GDP and subjective well-being during the Great Recession period in Europe. The club convergence analysis we proposed, allowed us to examine this relationship in a more comprehensive manner (i.e., between countries and within groups).

Such methodology allowed us to identify the presence of a "well-being gap" among European countries by isolating three different clubs of countries that converge to different steady-states and present similar features in terms of well-being. In line with other studies, our results indicate the Nordic countries as those with higher life satisfaction. However, we found an interesting dichotomy among transition countries. Some countries have made progress and are approaching the life satisfaction levels of some original EU members (i.e. France, Spain, Belgium), while others (low-income transition economies) are lagging behind by forming a club with low-growth Southern European countries.

Our analysis has shown contrasting findings about the relationship between economic growth and life satisfaction. Growth-dependent countries in which life satisfaction is extremely sensitive to economic business cycles (poorer and less satisfied) are opposed to countries in which life satisfaction flows independently from economic growth (richer and more satisfied). Furthermore, by using ordered probit regressions we have found a statistically significant association between the overall levels of life satisfaction and the quality of public institutions that, directly or indirectly, seem to mitigate the negative effects of economic shocks and preserve people's life satisfaction, especially in time of crisis.

Although the more developed transition countries have almost reached the life satisfaction levels of some original EU members, the process of (slow) convergence seems to have declined (or even reversed) in the aftermath of the Great Recession. It seems that the crisis has dramatically exposed individuals to anxiety, stress and dissatisfaction, with particular relevance for people living in more vulnerable areas (see Deaton 2012 for the US case).

Supporting the process of economic convergence remains a priority for policymakers. However, our findings indicate that relying only on income growth as key factor for social progress may lead to temporary, but not persistent, increase in life satisfaction. To ensure higher levels of well-being both in less developed transition economies and in peripheral (Southern) European countries, governments need to strengthen their institutions and, more important, they have to support the European cohesion strategy. The revision of anti-corruption regulation, with more severe penalties for corruption episodes combined to a better political stability, may enhance life satisfaction in the context of Southern and low-income European countries. Moreover, our findings suggest that increasing the matching in the labor market and ensuring greater social security for unemployed may reduce social inequalities. Therefore, policy solutions aimed at strengthening welfare systems may severely contribute to the process of well-being convergence in relatively less developed European countries. As institutions (and macroeconomic conditions) continue to improve, lagging countries may achieve quality of life levels comparable with those in the most advanced European countries. 


\section{References}

Andrews, F. M., \& Crandall, R. (1976). The validity of measures of self-reported well-being. Social Indicators Research, 3(1), 1-19. https://doi.org/10.1007/BF00286161

Arampatzi, E., Burger, M. J., Stavropoulos, S., \& Oort, F. G. (2019). Subjective well-being and the 2008 recession in European regions: The moderating role of quality of governance. International Journal of Community Well-Being, 2(2), 111-133. https://doi.org/10.1007/s42413-019-00022-0

Bjørnskov, C. (2003). The happy few: Cross-country evidence on social capital and life satisfaction. Kyklos, 55(1), 3-16. https://doi.org/10.1111/1467-6435.00207

Bjørnskov, C., Dreher, A., \& Fischer, J. A. (2007). The bigger the better? Evidence of the effect of government size on life satisfaction around the world. Public Choice, 130(3-4), 267292. https://doi.org/10.1007/s11127-006-9081-5

Bjørnskov, C., Dreher, A., \& Fischer, J. A. (2010). Formal institutions and subjective wellbeing: Revisiting the cross-country evidence. European Journal of Political Economy, 26(4), 419-430. https://doi.org/10.1016/j.ejpoleco.2010.03.001

Blokker, P. (2005). Post-communist modernization, transition studies, and diversity in Europe. European journal of social theory, 8(4), 503-525. https://doi.org/10.1177/1368431005059703

Bolea, L., Duarte, R., \& Chóliz, J. S. (2018). From convergence to divergence? Some new insights into the evolution of the European Union. Structural Change and Economic Dynamics, 47, 82-95. https://doi.org/10.1016/j.strueco.2018.07.006

Burgard, S. A., \& Kalousova, L. (2015). Effects of the Great Recession: Health and well-being. Annual Review of Sociology, 41, 181-201. https://doi.org/10.1146/annurev-soc-073014112204

Ciziceno, M., \& Travaglino, G. A. (2019). Perceived Corruption and Individuals' Life Satisfaction: The Mediating Role of Institutional Trust. Social Indicators Research, 141, 685-701. https://doi.org/10.1007/s11205-018-1850-2

Deaton, A. (2008). Income, health, and well-being around the world: Evidence from the Gallup World Poll. Journal of Economic Perspectives, 22(2), 53-72. https://doi.org/10.1257/jep.22.2.53

Deaton, A. (2012). The financial crisis and the well-being of Americans 2011 OEP Hicks Lecture. Oxford Economic Papers, 64(1), 1-26.

Delle, F., \& Antonella. (2014). Well-Being in Times of Crisis: Interdisciplinary Evidence and Policy Implications. Journal of Happiness Studies, 15(1), 119-123. https://doi.org/10.1007/s10902-014-9499-2

Di Tella, R., \& McCulloch, R. (2008). Gross national happiness as an answer to the Easterlin Paradox?. Journal of Development Economics, 86(1), 22-42. 
https://doi.org/10.1016/j.jdeveco.2007.06.008

Diener, E. D., Emmons, R. A., Larsen, R. J., \& Griffin, S. (1985). The satisfaction with life scale. Journal of Personality Assessment, 49(1), 71-75. https://doi.org/10.1207/s15327752jpa4901_13

Diener, E., \& Biswas-Diener, R. (2002). Will money increase subjective well-being? Social Indicators Research, 57(2), 119-169. https://doi.org/10.1023/A:1014411319119

Djankov, S., Nikolova, E., \& Zilinsky, J. (2016). The happiness gap in Eastern Europe. Journal of Comparative Economics, 44(1), 108-124. https://doi.org/10.1016/j.jce.2015.10.006

Easterlin, R. A. (1974). Does economic growth improve the human lot? Some empirical evidence. In David, P.A. and Melvin R. (Eds.), Nations and Households an Economic Growth, Academic Press, New York, 89-125.

Frey, B. S., \& Stutzer, A. (2000). Happiness, economy and institutions. The Economic Journal, 110(466), 918-938. https://doi.org/10.1111/1468-0297.00570

Frey, B. S., \& Stutzer, A. (2002). What can economists learn from happiness research? Journal of Economic Literature, 40(2), 402-435. https://doi.org/ 10.1257/002205102320161320

Frijters, P., Haisken-DeNew, J. P., \& Shields, M. A. (2004). Money does matter! Evidence from increasing real income and life satisfaction in East Germany following reunification. American Economic Review, 94(3), 730-740. https://doi.org/ 10.1257/0002828041464551

Fujita, F., \& Diener, E. (2005). Life satisfaction set point: stability and change. Journal of personality and Social Psychology, 88(1), 158-164. https://doi.org/10.1037/00223514.88.1.158

Graham, C., Chattopadhyay, S., \& Picon, M. (2010). Adapting to adversity: Happiness and the 2009 economic crisis in the United States. Social Research, 77(2), 715-748. https://doi.org/10.2307/40972235

Gruen, C., \& Klasen, S. (2012). Has transition improved well-being? Economic Systems, 36(1), 11-30. https://doi.org/10.1016/j.ecosys.2011.09.002

Guriev, S., \& Melnikov, N. (2018). Happiness convergence in transition countries. Journal of Comparative Economics, 46(3), 683-707. https://doi.org/10.1016/j.jce.2018.07.003

Guriev, S., \& Zhuravskaya, E. (2009). (Un) happiness in transition. Journal of Economic Perspectives, 23(2), 143-168. https://doi.org/10.1257/jep.23.2.143

Headey, B., \& Wooden, M. (2004). The effects of wealth and income on subjective well-being and ill-being. Economic Record, 80, S24-S33. https://doi.org/10.1111/j.14754932.2004.00181.x

Helliwell, J. F., Huang, H., \& Wang, S. (2014a). Social capital and well-being in times of crisis. Journal of Happiness Studies, 15(1), 145-162. https://doi.org/10.1007/s10902-013-9441Z 
Helliwell, J. F., Huang, H., Grover, S., \& Wang, S. (2014b). Good Governance and National Well-being: What Are the Linkages? OECD Working Papers on Public Governance, 25, OECD Publishing, Paris, https://doi.org/10.1787/5jxv9f651hvj-en.

Iwanicz-Drozdowska, M., Smaga, P., \& Witkowski, B. (2016). Financial Development. Have Post-Communist Countries Converged? Transformations in Business \& Economics, 15(2A), 389-414.

Kaufmann, D., Kraay, A., \& Mastruzzi, M. (2010). The Worldwide Governance Indicators: A Summary of Methodology, Data and Analytical Issues. World Bank Policy Research, Working Paper No. 5430. Netrieved from http://papers.ssrn.com/sol3/papers.cfm?abstract_id=1682130.

Kelley, J., \& Evans, M. D. R. (2017). Societal Inequality and individual subjective well-being: Results from 68 societies and over 200,000 individuals, 1981-2008. Social science research, 62, 1-23. https://doi.org/10.1016/j.ssresearch.2016.04.020

Lucas, R. E., Diener, E., \& Suh, E. (1996). Discriminant validity of well-being measures. Journal of personality and Social Psychology, 71(3), 616-628. https://doi.org/10.1037/0022-3514.71.3.616

MacLeod, A. K. (2015). Well-being: Objectivism, subjectivism or sobjectivism?. Journal of Happiness Studies, 16(4), 1073-1089. https://doi.org/10.1007/s10902-014-9561-0

Mazzola, F., Pizzuto, P. (2020). Great Recession and club convergence in Europe: A crosscountry cross-region panel analysis (2000-2015). Growth and Change. https://doi.org/10.1111/grow.12369

Modrek, S., Hamad, R., \& Cullen, M. R. (2015). Psychological well-being during the great recession: changes in mental health care utilization in an occupational cohort. American Journal of Public Health, 105(2), 304-310. https://doi.org/10.2105/AJPH.2014.302219

Nikolova, M. (2016). Minding the happiness gap: Political institutions and perceived quality of life in transition. European Journal of Political Economy, 45, 129-148. https://doi.org/10.1016/j.ejpoleco.2016.07.008

North, D. C. 1990. Institutions, institutional change and economic performance. Cambridge, UK: Cambridge University Press.

Norton, E. C., Nizalova, O., \& Murtazashvili, I. (2018). Does past unemployment experience explain the transition happiness gap? Journal of Comparative Economics, 46(3), 736-753. https://doi.org/10.1016/j.jce.2018.07.005

Oishi, S., Diener, E. F., Lucas, R. E., \& Suh, E. M. (1999). Cross-cultural variations in predictors of life satisfaction: Perspectives from needs and values. Personality and Social Psychology Bulletin, 25(8), 980-990. https://doi.org/10.1177/01461672992511006

Okulicz-Kozaryn, A. (2012). Income and well-being across European provinces. Social Indicators Research, 106(2), 371-392. https://doi.org/10.1007/s11205-011-9812-y 
Okulicz-Kozaryn, A., \& Mazelis, J. M. (2017). More unequal in income, more unequal in wellbeing. Social Indicators Research, 132(3), 953-975. https://doi.org/10.1007/s11205016-1327-0

Phillips, P. C., \& Sul, D. (2007). Transition modeling and econometric convergence tests. Econometrica, 75(6), 1771-1855. https://doi.org/10.1111/j.1468-0262.2007.00811.x

Phillips, P. C., \& Sul, D., (2009). Economic transition and growth. Journal of Applied Econometrics, 24(7), 1153-1185. https://doi.org/10.1002/jae.1080

Sichera, R., Pizzuto, P. (2019) Convergence Clubs: A Package for Performing the Phillips and Sul's Club Convergence Clustering Procedure. The $R$ Journal, 11(2), 142-151. https://doi.org/10.32614/RJ-2019-021

Von Lyncker, K., \& Thoennessen, R. (2017). Regional club convergence in the EU: evidence from a panel data analysis. Empirical Economics, 55(2), 525-553. https://doi.org/10.1007/s00181-016-1096-2

Welsch, H., \& Bonn, U. (2008). Economic convergence and life satisfaction in the European Union. The Journal of Socio-Economics, 37(3), 1153-1167. https://doi.org/10.1016/j.socec.2006.12.07

\section{Notes}

Note 1. We follow the definition of formal institutions provided by North (1990) (i.e. we refer to regulatory, political, and economic institutions).

Note 2. See for example, the World Values Survey, the Eurobarometer Survey (Frey and Stutzer 2002) and the European Social Survey.

Note 3. Data constraints prevented us to use a larger time sample since Eurobarometer comparable data for the broad sample of countries belonging to EU-28 are not available before 2005.

Note 4. As a result of Monte Carlo simulations Phillips and Sul suggest to use $r=[0.2,0.3]$ for small sample size $(T<50)$. See Phillips and Sul $(2007,2009)$ for more details.

Note 5. All the procedures described in this paragraph are performed using the $\mathrm{R}$ package "ConvergenceClubs: Finding Convergence Clubs" developed by Sichera and Pizzuto (2019).

Note 6. Following Phillips and Sul $(2007,2009)$ log-t tests have been performed using filtered time series (Hodrick-Prescott (HP) filter), choosing the value of 100 as a smoothing parameter.

Note 7. Although the point estimates of the beta coefficients associated to Clubs 1 and 2 are negative, they are not significantly less than zero.

Note 8 . As an additional robustness check we re-estimated our model using the cumulative percentage of very and fairly satisfied people (i.e. the top two categories). The estimates presented in Table A2 in the appendix show very similar and broadly unchanged results 
suggesting that our findings are not sensitive to the selected category.

Note 9. Data in parentheses refers to 2017.

Note 10. The coefficients of correlation between average life satisfaction and average percapita GDP growth are $0.09,-0.03,0.69$, for club 1, club 2 and club 3, respectively.

Note 11. Results should be interpreted with some caution due to the not very large crosssectional dimension $(\mathrm{N}$. observations $=27)$.

Note 12. We performed additional robustness checks using the club membership as in Table A2 in the appendix (i.e. using the cumulative percentage of very and fairly satisfied people). Also in this case, the estimates presented in Table A3 in the appendix show very similar and broadly unchanged results to those presented in the text. 
Appendix

Table A1. Descriptive Statistics on Very Satisfied People

\begin{tabular}{lccccc}
\hline \multicolumn{1}{c}{ Country } & Average $(\%)$ & Min $(\%)$ & Max $(\%)$ & $\begin{array}{c}\text { Coefficient } \\
\text { of Variation }\end{array}$ & Ranking \\
\hline Austria & 23.49 & 16.98 & 35.31 & 0.26 & 13 \\
Belgium & 29.64 & 27.05 & 32.22 & 0.06 & 9 \\
Bulgaria & 3.59 & 2.24 & 6.43 & 0.37 & 27 \\
Croatia & 16.34 & 14.85 & 18.10 & 0.06 & 16 \\
Cyprus & 30.24 & 19.82 & 35.05 & 0.13 & 8 \\
Czech Republic & 13.87 & 10.27 & 18.26 & 0.18 & 17 \\
Denmark & 68.54 & 64.77 & 72.66 & 0.04 & 1 \\
Estonia & 10.04 & 7.35 & 14.54 & 0.23 & 22 \\
Finland & 35.23 & 31.02 & 41.40 & 0.07 & 7 \\
France & 19.16 & 16.10 & 23.29 & 0.12 & 14 \\
Germany & 25.67 & 19.01 & 33.14 & 0.18 & 11 \\
Greece & 6.57 & 3.39 & 12.91 & 0.50 & 25 \\
Hungary & 7.05 & 4.94 & 10.85 & 0.29 & 24 \\
Ireland & 35.56 & 25.22 & 46.27 & 0.17 & 6 \\
Italy & 7.76 & 5.28 & 13.11 & 0.32 & 23 \\
Latvia & 10.07 & 7.18 & 14.46 & 0.23 & 21 \\
Lithuania & 12.32 & 9.73 & 15.64 & 0.17 & 20 \\
Luxembourg & 41.17 & 34.10 & 48.38 & 0.10 & 4 \\
Malta & 28.32 & 21.52 & 36.47 & 0.15 & 10 \\
Netherlands & 50.57 & 45.88 & 53.41 & 0.05 & 2 \\
Poland & 13.36 & 10.35 & 17.96 & 0.16 & 18 \\
Portugal & 3.57 & 1.33 & 5.57 & 0.43 & 28 \\
Romania & 5.97 & 4.12 & 9.08 & 0.27 & 26 \\
Slovakia & 12.82 & 8.81 & 16.71 & 0.18 & 19 \\
Slovenia & 24.15 & 18.57 & 31.32 & 0.15 & 12 \\
Spain & 17.68 & 12.48 & 23.47 & 0.19 & 15 \\
Sweden & 47.87 & 45.88 & 49.25 & 0.02 & 3 \\
United Kingdom & 38.46 & 32.05 & 46.94 & 0.12 & 5 \\
\hline & & & & & \\
\hline
\end{tabular}

Note: The ranking is based on the average value of the period 2005-2017 
Table A2. Convergence Clubs in Life Satisfaction (Club Merging Methodologies - Very and Fairly Satisfied

\begin{tabular}{cclccc}
\hline Club & n. Countries & \multicolumn{1}{c}{ Members } & beta & se & t-stat \\
\hline 1 & 10 & $\begin{array}{l}\text { Denmark, Ireland, Malta, Netherlands, Luxembourg, } \\
\text { Sweden, Finland, United Kingdom, Germany, Belgium } \\
\text { Slovenia, Czech Republic, Austria, Poland, France, }\end{array}$ & 0.870 & 0.232 & 3.753 \\
2 & $12 \quad \begin{array}{l}\text { Portugal, Hungary, Cyprus, Estonia, Spain, Latvia, } \\
\text { Lithuania }\end{array}$ & 0.145 & 0.100 & 1.452 \\
3 & 5 & Italy, Romania, Slovakia, Croatia, Bulgaria & 0.098 & 0.049 & 2.001 \\
\hline
\end{tabular}

Note: Greece is diverging country

Table A3. Ordered Probit Results - Very and Fairly Satisfied
(1)
(2)
(3)
(4)
(5)
(6)

\begin{tabular}{|c|c|c|c|c|c|c|}
\hline Political Stability & $\begin{array}{l}1.491 * \\
(0.822)\end{array}$ & & & $\begin{array}{c}2.325 * * * \\
(0.837)\end{array}$ & & $\begin{array}{c}3.490 \\
(2.291)\end{array}$ \\
\hline Control of corruption & $\begin{array}{c}2.316^{* * *} \\
(0.682)\end{array}$ & & & & $\begin{array}{c}2.573 * * * \\
(0.716)\end{array}$ & $\begin{array}{c}2.815^{* *} \\
(1.123)\end{array}$ \\
\hline Unemployment rates & & $\begin{array}{l}-0.223 * \\
(0.124)\end{array}$ & & $\begin{array}{l}-0.273 * \\
(0.142)\end{array}$ & & $\begin{array}{l}-0.191 \\
(0.190)\end{array}$ \\
\hline Income inequality & & $\begin{array}{l}-0.0997 * \\
(0.0529)\end{array}$ & & & $\begin{array}{c}0.0116 \\
(0.0713)\end{array}$ & $\begin{array}{l}0.0871 \\
(0.126)\end{array}$ \\
\hline Schooling & & & $\begin{array}{c}0.268 * * * \\
(0.0932)\end{array}$ & $\begin{array}{c}0.312 * * * \\
(0.105)\end{array}$ & & $\begin{array}{l}0.454 * \\
(0.262)\end{array}$ \\
\hline Age of population & & & $\begin{array}{c}0.102 \\
(0.117)\end{array}$ & & $\begin{array}{l}-0.124 \\
(0.143)\end{array}$ & $\begin{array}{c}0.109 \\
(0.274)\end{array}$ \\
\hline LR & 30.91 & 7.96 & 9.46 & 24.71 & 28.21 & 39.68 \\
\hline Prob $>$ chi 2 & 0.000 & 0.019 & 0.009 & 0.000 & 0.000 & 0.000 \\
\hline Pseudo $\mathrm{R}^{2}$ & 0.550 & 0.142 & 0.168 & 0.440 & 0.502 & 0.706 \\
\hline
\end{tabular}

Note: $\quad * \mathrm{p}<0.10 ; * * \mathrm{p}<0.05 ; * * * \mathrm{p}<0.01$ (SE indicated in parentheses) N. observations $=27$

\section{Copyright Disclaimer}

Copyright for this article is retained by the author(s), with first publication rights granted to the journal.

This is an open-access article distributed under the terms and conditions of the Creative Commons Attribution license (http://creativecommons.org/licenses/by/3.0/). 